\title{
Reluctance Network Analysis Model of a Switched Reluctance Motor Taking Account of Iron Loss
}

\author{
S. Fujio, K. Nakamura, and O. Ichinokura \\ Graduate School of Engineering, Tohoku University, Aoba6-6-05, Aramaki, Aoba-ku, Sendai 980-8579, Japan
}

\begin{abstract}
This paper presents a method for calculating the iron loss characteristics of a switched reluctance (SR) motor based on reluctance network analysis (RNA). The RNA model of the SR motor consists of a multiple number of nonlinear reluctances and magnetomotive forces (MMFs) exerted by a winding current. In addition to these elements, magnetic inductances that express the magnetic hysteresis are incorporated into the model. The RNA model of the SR motor is combined with its drive circuit and motion calculation circuits in SPICE, which is a general-purpose circuit simulator. Using the electromagnetic and motion-coupled models, we can calculate dynamic characteristics, including iron loss, quickly and accurately. We evaluate the validity of the proposed method by comparing the result with measured values.
\end{abstract}

Key words: switched reluctance (SR) motor, reluctance network analysis (RNA), iron loss, SPICE

\section{磁気ヒステリシスを考慮したスイッチトリラクタンスモータの RNA モデル}

藤尾真也, 中村健二, 一八倉理

東北大学大学院工学研究科, 仙台市青葉区荒巻字青葉 6-6-05 (广 980-8579)

\section{1. はじめに}

スイッチトリラクタンス（SR）モータは，固定子，回転子とも に突極構造を有しており，磁気回路の磁気抵抗变化に起因するリ ラクタンストルクを利用して回転するモータである. 巻線は固定 子極にの集中巻され，回転子には巻線や永久磁石を必要としな い. 従って, SRモータは構造が極めて簡単で堅牢かつ安価, 高速 回転に適する, 而熱性に優れるなどの特長を有している11,2).また， 近年のパワーエレクトロニクス技術の進展により，モータのきめ 細やかな制御が可能になり，これまで指摘されていたトルクリプ ルや騒音などの問題についても改善が進んでいる3),4). そのため, 最近では洗濯機や掃除機などへの実用化も始まっており，今後は 電気自動車や電動二輪車への応用も期待されている5)-7).

一般にモータの最適設計法としては，有限要素法 (FEM) を用 いたモータ形状の最適化などが挙げられるが, SR モータの場合に は，励磁条件によってもモ一夕特性が大きく左右されるため，モ 一タ形状の最適設計に加えて, 駆動回路であるコンバータや制御 系まで含めたシステム全体の最適設計が必要不可欠である. 最近 では，モー夕運転状態での電磁界解析も可能な有限要素法プログ ラムもいくつか市販されているが，良好な計算精度を得るために は十分な計算機容量と計算時間を必要とする. また，制御系まで 含めた解析については，現状の有限要素法では必ずしも容易では なく，簡便かつ高速で精度の高い解析手法が望まれる.

これに対して, 磁気回路法は起磁力と磁束の関係を集中定数回 路で扱うことにより, 機器内部の磁気現象を巨視的に解析する手 法である. 機器の形状を反映したシンプルな解析モデルが構築で きるため, 簡便な計算で機器の動作原理を容易に把握することが できる. 外部の電気・電子回路との連成解析も容易であり, 計算 にはSPICEなどの汎用の回路シミュレータを利用できる.

上記の考えに基づき，筆者らは解析対象である電気機器を複数 の要素に分割し，それぞれを磁気抵抗に置き換えることで，機器
全体を一つ磁気抵抗回路網としてモデル化して解析寸る, いわ ゆるリラクタンスネットワーク解析（以下，RNAと略記）による SRモータの動特性算定手法について検討を進めている8), 9). 本手 法を用いれば, 駆動回路の挙動からモータ内部の磁束分布, トル クおよび速度の変動までも同時に計算することができる.

本稿では, 従来の SR モータの RNA モデルを改良し, 鉄損まで 考慮可能なモデルについて検討を行ったので報告する.

\section{2. $\mathrm{SR} モ$ モの構造と原理}

Fig. 1 に，考察に使用した固定子 6 極，回転子 4 極の三相SRモ 一タを示す. 磁心材質は, 厚さ $0.35 \mathrm{~mm}$ 無方向性電磁鋼板であ る. Fig. 2 は, SRモータの駆動回路である非対称ハーフブリッジ コンバータである. 以下の考察では, $\mathrm{A}$ 相の固定子極と回転子極が 対向したときの回転子位置角を $\theta=0^{\circ}$ とし, 時計回りの方向を回転 の正方向とする.この場合, $\mathrm{A}$ 相のインダクタンスは $\theta=0^{\circ}$ で最大, $\theta= \pm 45^{\circ}$ で最小になる. Fig. 3 に, A相の巻線インダクタンスの回 転子位置角 $\theta$ に対する変化と, 励磁電圧, および巻線電流の概略 波形を示す. 図中のV VCは励磁電圧の振幅である. $\theta_{\mathrm{w}}$ および $\theta \mathrm{b}$ は, それぞれ励磁幅および厉磁開始角である.

$\mathrm{SR}$ モータの一相当りのトルク $\tau$ は, 磁気特性を線形と仮定すれ ば，以下の式で与えられる.

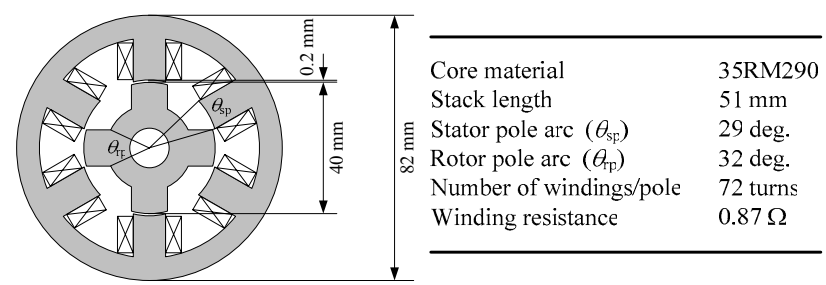

Fig. 1 Specifications of the 6/4-pole SR motor used in the calculation. 


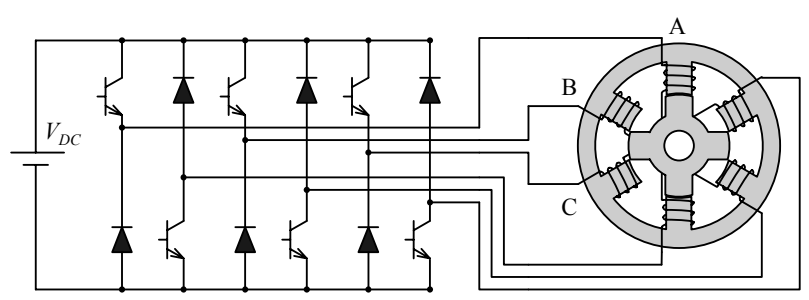

Fig. 2 Drive circuit for the SR motor.

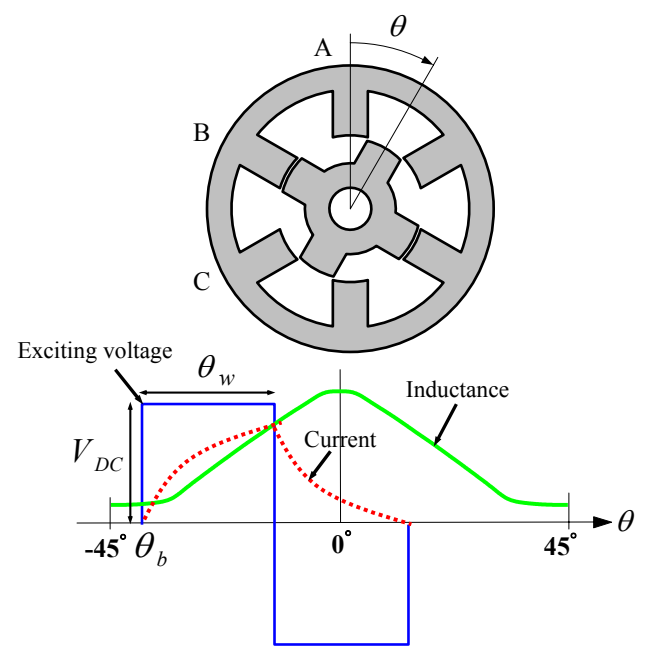

Fig. 3 Schematic diagram of phase-A inductance, exciting voltage, and winding current relative to the rotor angle.

$$
\tau=\frac{1}{2} i^{2} \frac{d L(\theta)}{d \theta} .
$$

従って，インダクタンスの傾きが正の領域で励磁を行えば，回転 方向と同一のトルクが得られる.

\section{RNAに基づくSRモータの動特性算定手法8).9)}

\section{3. $1 \mathrm{RNA}$ モデルの導出方法}

以下では, 先に筆者らが提案した SR モータのRNA モデルの導 出方法と, 駆動回路並びに回転運動系を結合した電気 - 磁気 - 運 動連成解析手法について述べる.

まずFig. 4に示すように, SR モータをいくつかの要素に分割し， それぞれの要素を寸法および材料の磁気特性で決まる非線形磁気 抵抗で置き換える. 非線形磁気抵抗の導出方法については，以下 の通りである.

鉄心の非線形磁気特性を考慮すると， $B-H$ 曲線は次の式で近似 できる.

$$
H=\alpha_{1} B+\alpha_{\mathrm{m}} B^{\mathrm{m}} .
$$

ここで, $\alpha_{1}$ および $\alpha_{\mathrm{m}}$ は係数である. 次数 $m$ は 3 以上の奇数であり, 磁気特性の非線形性の強さに応じて適切に選ぶ必要があるが，こ こでは $m=7$ とした，磁路の断面積を $S$ ，長さをlとすれば，起磁力 $f_{\mathrm{m}}$, 磁気抵抗 $R_{\mathrm{m}}$, および磁束 $\phi$ の関係は，(2)式に基づき次式で与 えられる.

$$
\begin{aligned}
f_{\mathrm{m}} & =R_{\mathrm{m}} \phi \\
& =\left(\frac{\alpha_{1} l}{S}+\frac{\alpha_{7} l}{S^{7}} \phi^{6}\right) \phi .
\end{aligned}
$$

上式の括弧内が非線形磁気抵抗に相当する.

次いで, 磁極周辺の磁気抵抗の導出方法であるが, SR モー夕は 突極構造を有することから, 回転子位置角により磁極周辺の磁束 分布がダイナミックに変化する. Fig. 5 に, 固定子極と回転子極の 一部が対向した位置関係にあるときの磁極周辺の磁束の流れを示 す。同図より，磁束は極同士が対向した部分に集中して流れるこ とがわかる．これにより極先端部では磁気飽和が生じ易くなるた め, 解析においてもこれを考慮できるようにモデリングする必要 がある.

Fig. 6 に磁極周辺の要素分割と, これに対応した磁気回路を示寸. 上述の磁気飽和を考慮するために, 極先端部は 2 つの要素に分割 する. また, 空隙部はフリンジング磁束も考慮するため, 3 つの要 素に分割した. なお，これらの要素の寸法は回転子位置角によっ て変化するため, 鉄心部については非線形の可変磁気抵抗, 空隙 部については線形の可変磁気抵抗で置き換える.

以上により, 導出された SR モータの RNA モデルを Fig. 7 に示 す. 同図中の従属電源は, 巻線電流による起磁力である. また, 固定子極からヨークおよび隣接する極への漏れ磁束も無視できな いため, 同図に示寸ように極間および極 - ヨーク間に漏孔磁気抵 抗を配置した.
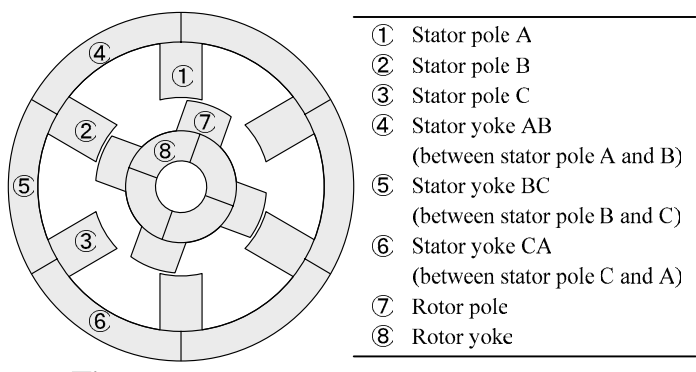

Fig. 4 Element division of the motor iron.

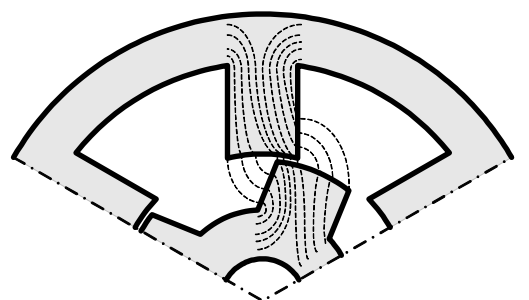

Fig. 5 Diagram of the flux flow around stator and rotor poles in the case of partial overlapping.

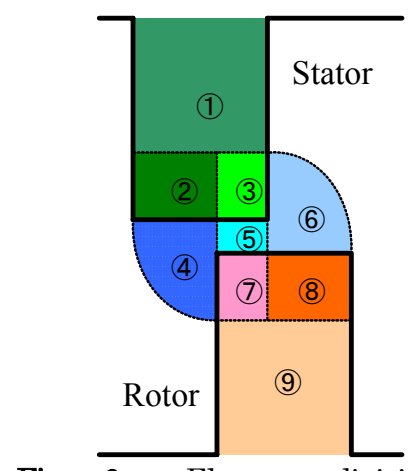

Fig. 6 Element division around poles and the corresponding magnetic circuit.

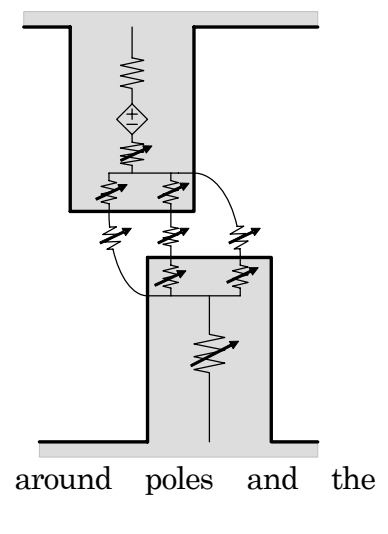




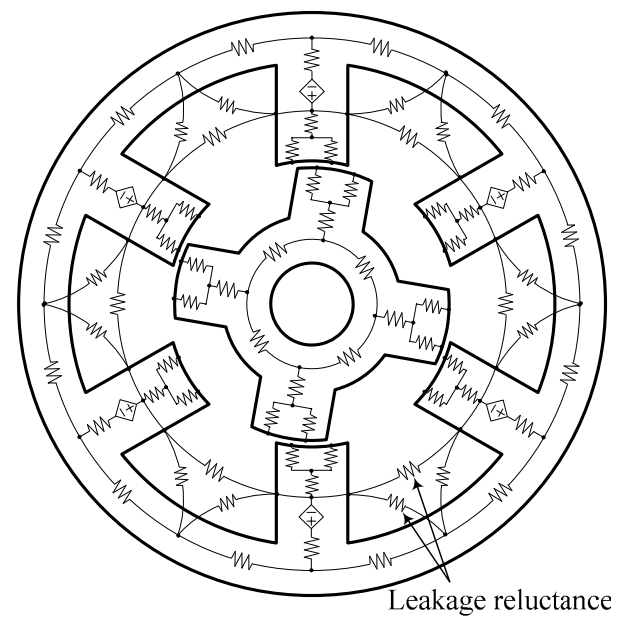

Fig. 7 Proposed RNA model of the SR motor.

\section{3. $2 \mathrm{SR}$ モータの電気 - 磁気 - 運動連成モデル}

前節までの考察により, SR モータのRNA モデルが導出された. 一般に，モータトルク $\tau$ は磁気エネルギーから

$$
\tau=-\frac{\partial W_{\mathrm{FM}}(\phi, \theta)}{\partial \theta} \text {. }
$$

で求めることができるので，Fig. 7 のNAモデルを用いて種々の 回転子位置角に対する磁化曲線を算出し，これを適当な数式で表 せば，磁気エネルギー並びにトルクが計算できる10).

Fig. 8 に，上述のRNA モデルと駆動回路，およびトルクや運動 方程式を計算する回転運動系を結合した, SR モータの電気 - 磁気 - 運動連成モデルを示す. 本連成モデルは, 汎用の電気・電子回 路シミュレータである SPICE 上ですべて回路表現できるため, 電 気系, 磁気系, ならびに運動系の同時連成解析が可能になる. Fig. 9 に, 本連成モデルを用いて算定した SR モータのトルク - 速度特 性を示す. 励磁開始角は-37.2 deg., 励磁幅は 30.0 deg., 直流電源 電圧は 40，60，80 Vである．この図を見ると，計算值と実測值は ほぼ良好に一致しており, 本手法の妥当性が了解される.

Fig. 10 に, SR モータ各部の磁束密度波形の算定結果を示す. 図中の実線がRNAによる計算值である. 比較のため, 三次元有限 要素法により求めた結果についても, 同図中のシンボルで示す. この図を見ると, 両者は大略一致しており, 本手法でモータ各部 の磁束密度分布も精度良く算定できることが了解される.

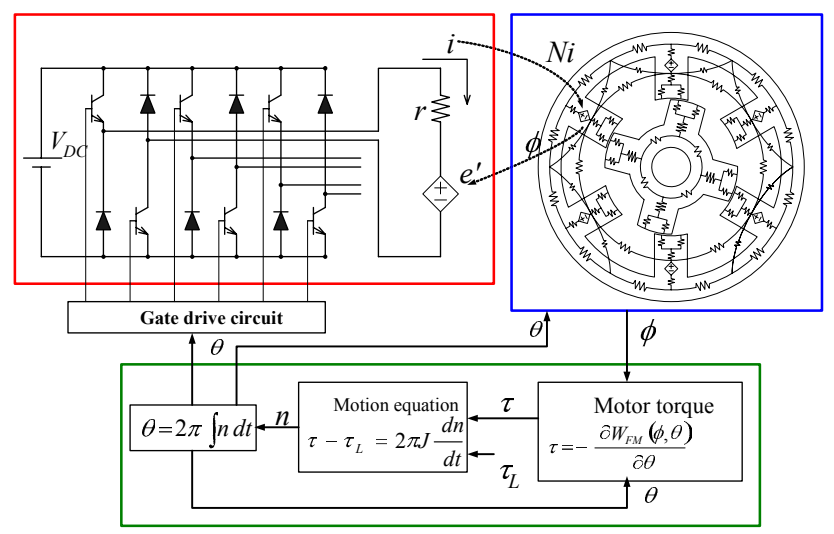

Fig. 8 Electromagnetic and motion-coupled model of the SR motor.

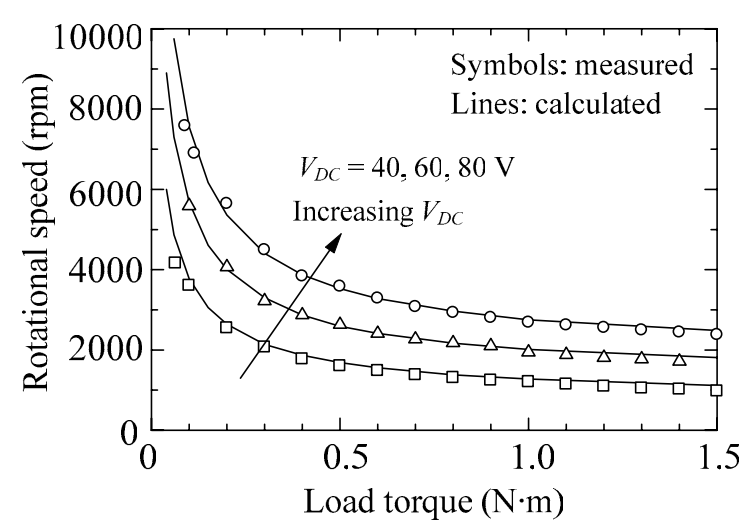

Fig. 9 Rotational speed versus torque characteristics of the SR motor.
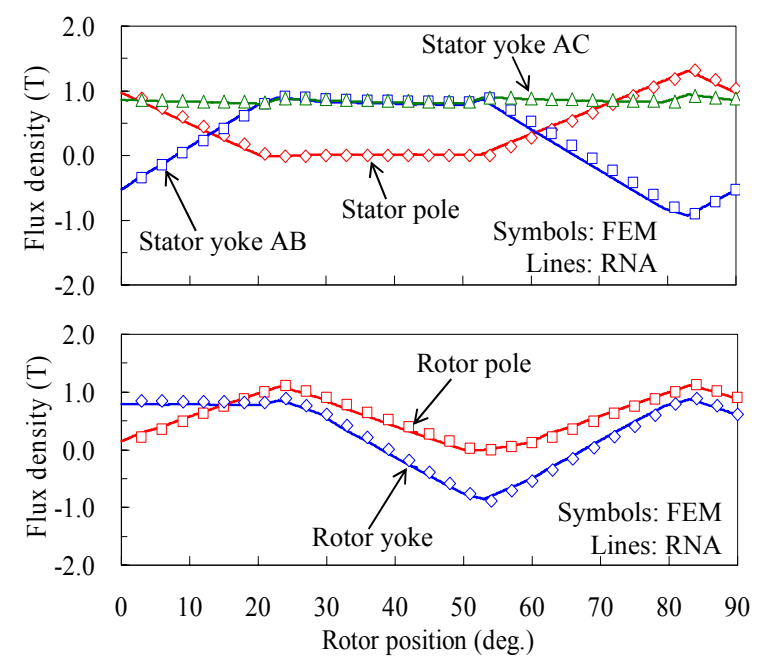

Fig. 10 Calculated flux density waveform of each part of the SR motor.

\section{4. 鉄損を考慮した RNA モデル}

\section{1 鉄損を考慮した RNA モデルの導出方法}

SR モータの RNA モデルを用いて鉄損を算定するためには, 材 料のヒステリシスループを考慮する必要がある. Fig. 11 に, 材料 の $B-H$ 曲線の概略を示す. 図中の破線は, ヒステリシスループを 無視した場合の $B-H$ 曲線であり，(2)式で表される.

一方，ヒステリシスループを考慮した場合， $B-H$ 曲線は同図の 実線のような軌跡を描く.ここで, 同図中の動作点 a における磁 界強度は磁束密度に比例する成分と, 磁束密度の時間微分に比例 する成分を用いて, 次式で表すことができる.

$$
H=\alpha_{1} B+\alpha_{\mathrm{m}} B^{\mathrm{m}}+\beta_{1} \frac{d B}{d t} .
$$

上式の右辺第 1 項と第 2 項が鉄心の非線形磁気特性を表しており, 第 3 項がヒステリシスループを表している. (5)式に基づき, 起磁 力 $f_{\mathrm{m}}$ と磁束 $\phi$ の関係は, 次式で与えられる.

$$
\begin{aligned}
f_{\mathrm{m}} & =R_{\mathrm{m}} \phi+R_{\mathrm{m}}{ }^{\prime} \frac{d \phi}{d t} \\
& =\left(\frac{\alpha_{1} l}{S}+\frac{\alpha_{\mathrm{m}} l}{S^{\mathrm{m}}} \phi^{\mathrm{m}-1}\right) \phi+\frac{\beta_{1} l}{S} \frac{d \phi}{d t} .
\end{aligned}
$$


(6)式よりRNAにおいては, モデル中の磁気抵抗 $R_{\mathrm{m}}$ にインダクタン ス $R_{\mathrm{m}}{ }^{\prime}$ を直列に接続することによって，ヒステリシスループが表現 できることが了解される.

次に，係数 $\beta_{1}$ の導出方法について述べる. $\beta_{1}$ は, 材料の鉄損曲線 $\left(W_{\mathrm{i}}-B_{\mathrm{m}}\right.$ 曲線 $)$ から求めることができる11). 但し, 通常各鉄鋼义 一力より提供されている鉄損曲線は，磁束密度波形が正弦波の場 合のみであり, Fig. 10 に示したような歪み波の場合の鉄損曲線は, 別途何らかの方法で求める必要がある. 本稿では, 以下の手順に 従つて求めた.

まず，Fig. 10 に示したモータ各部の磁束密度波形をフーリエ級 数に展開し, 各調波の振幅 $B_{k \mathrm{~m}}$ を算出寸る. 得られた $B_{k \mathrm{~m}}$ から第 $k$ 調 波の鉄損 $w_{k i}$ は, 次式を用いて計算できる.

$$
w_{k \mathrm{i}}=A_{\mathrm{h}} k f B_{k \mathrm{~m}}^{\mathrm{n}}+A_{\mathrm{e}}(k f)^{2} B_{k \mathrm{~m}}^{2} . \quad(n=1.6 \sim 2.0)
$$

ここで, $A_{\mathrm{h}}$ はヒステリシス損係数, $A_{\mathrm{e}}$ は渦電流損係数であり, 本稿 では加工劣化の影響を考慮するため実測值を用いている. 次いで, 各調波の鉄損 $w_{k i}$ の和から全体の鉄損 $W_{\mathrm{i}}$ を求める，上記の計算を最 大磁束密度 $B_{\mathrm{m}}$ を種々変えて行えば，磁束密度波形に対応した鉄損 曲線を得ることができる. 最後に，導出した鉄損曲線を適切な関 数で近似すれば，磁束密度波形に固有の $\beta_{1}$ を求めることができる.

鉄損曲線を近似する関数は, 次のようにして導くことができる. 鉄損 $W$ は で与えられる.

$$
\begin{aligned}
W_{\mathrm{i}} & =\frac{1}{T q} \int_{B(t=0)}^{B(t=T)} H d B \\
& =\frac{1}{T G_{\mathrm{m}}} \int_{\phi(t=0)}^{\phi(t=T)} f_{\mathrm{m}} d \phi .
\end{aligned}
$$

上式中の $q$ は磁心の重量密度, $G_{\mathrm{m}}$ は磁心の重量である. また, 任意 の磁束密度波形はフーリ工級数を用いて，次式で表すことができ る.

$$
B=B_{\mathrm{m}}\left\{b_{0}{ }^{\prime}+\sum_{k=1}^{n}\left(b_{k}{ }^{\prime} \cos \omega k t+a_{k}{ }^{\prime} \sin \omega k t\right)\right\} .
$$

$B_{\mathrm{m}}$ は最大磁束密度, $\omega$ は角速度, $b_{0}{ }^{\prime}, b_{k}{ }^{\prime}$ および $a_{k}{ }^{\prime}$ は係数である. よって，(8)式に(6)式および(9)式を代入すれば, 鉄損 $W_{\mathrm{i}}$ は最大磁束 密度 $B_{\mathrm{m}}$ の関数として, 次式で与えられる.

$$
W_{\mathrm{i}}=\left\{\frac{2 \pi^{2}}{q} \beta_{1} \sum_{k=1}^{n}\left(b_{k}{ }^{\prime 2}+a_{k}{ }^{\prime 2}\right) k^{2}\right\} f^{2} B_{\mathrm{m}}^{2} .
$$

従って，(10)式を用いて鉄損曲線を近似すれば, 係数 $\beta_{1}$ 求めるこ とができる.

Fig. 12 に，回転数が $3300 \mathrm{rpm}$ の場合における，モータ各部の 磁束密度波形に対応した鉄損曲線と, (10)式から求めた近似曲線を 示す. 種々の回転数についても同様に $\beta_{1}$ を算出すれば, 回転数に対 する依存性を得ることができる. Fig. 13 に, 各回転数に対する $\beta_{1}$ の 值を示す.この図から， $\beta_{1}$ は回転数, すなわち周波数に反比例する ことが了解される.

以上のようにして導出した，鉄損まで考慮可能な SR モータの RNA モデルを Fig. 14 に示寸. Fig. 7 の従来モデルと比較して, ヒステリシスループを表現するためのインダクタンスが，磁気回
路の各部に挿入されていることがわかる. このモデルにおいて鉄 損は，磁気回路中のインダクタンスに蓄えられるエネルギーから 算出される。

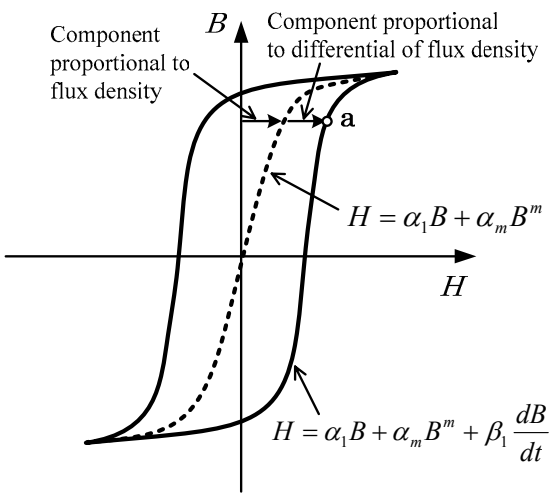

Fig. 11 Schematic diagram of the $B$ - $H$ curve.
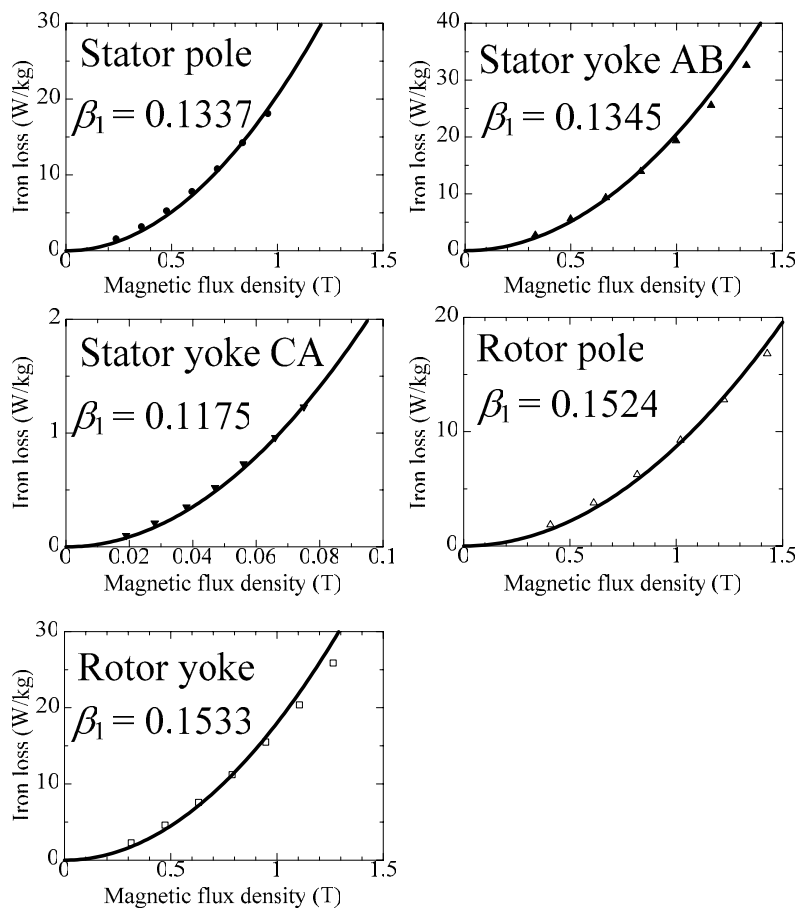

Fig. 12 Iron loss curves and approximated curves (at 3300 rpm).

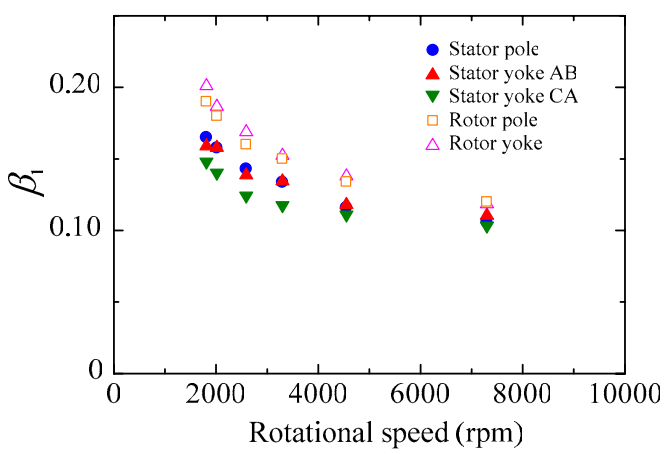

Fig. $13 \beta_{1}$ versus rotational speed characteristics. 


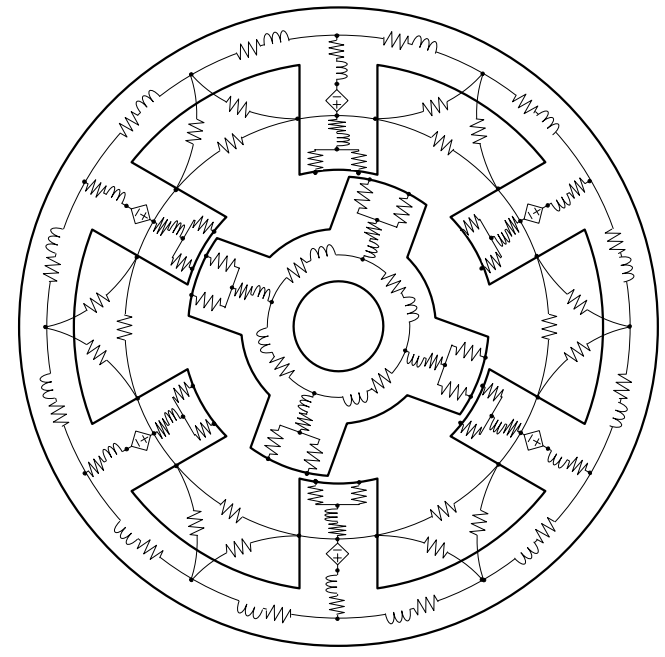

Fig. 14 RNA model of the SR motor taking account of iron loss.

\section{2 鉄損の算定結果}

Fig. 15 に励磁電圧 $60 \mathrm{~V}$, 励磁開始角-37.2 deg., 励磁幅 $30 \mathrm{deg}$. とした場合の SR モ一タの鉄損特性の算定值と実測值を示す. 実測 值については機械損を分離した值であり，測定のばらつきをエラ 一バーで示している.この結果を見ると，算定值と実測值は定性 的にも定量的にもおおむね良好に一致していることが了解される。

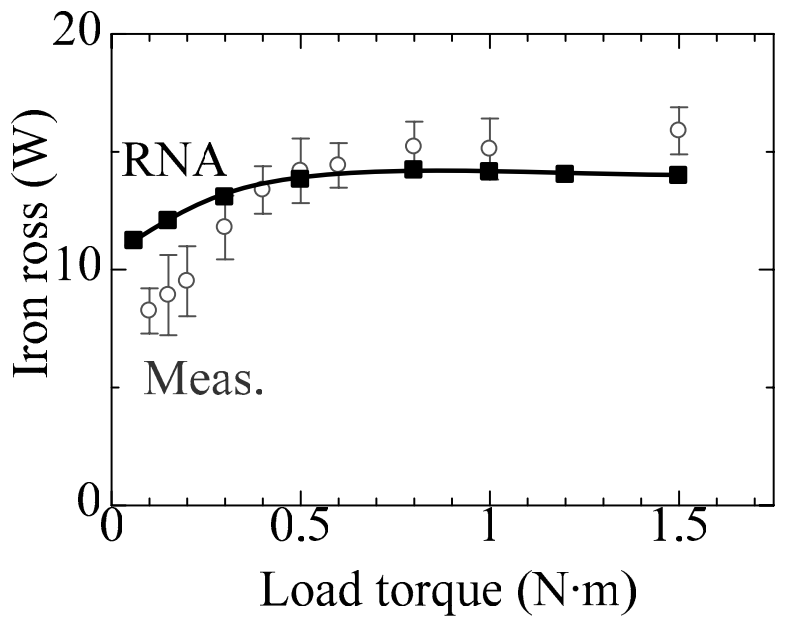

Fig. 15 Iron loss versus torque characteristics.

\section{5. まとめ}

以上, 鉄損を考慮した SR モータの RNA モデルの導出方法につ いて述へ，実測值との比較から本モデルの妥当性について検討を 行った.

従来，磁束密度が正弦波の場合の鉄損曲線は既知であり，ここ から導出されるインダクタンスを，磁気回路の磁気抵抗に対して 直列に接続することで，鉄損を算定することは可能であった．今 回新たに行った検討により，磁束密度が歪み波の場合であっても， 任意の歪み波に対応した鉄損曲線を導出することが可能になり， この鉄損曲線から求めたインダクタンスを用いれば, SR モータの 鉄損を精度良く算定できることが明らかになった。

従って, 本手法を用いればSR モータ単体の効率や, 駆動回路ま で含めたモータドライブシステム全体の効率についても評価が可 能になり，システムの最適設計に有用であると考えられる.

\section{References}

1) R. C. Becerra, M. Ehsani, and T. J. E. Miller, IEEE Trans. Power Electron., 8, 257 (1993).

2) N. Matsui and Y. Takeda, IEE Japan, 118-D, 685 (1998) [in Japanese].

3) S. Mir, M. E. Elbuluk, and I. Husain, IEEE Trans. Ind. Applicat., 35, 461 (1999).

4) K. M. Rahman and S. E. Schulz, IEEE Trans. Ind. Applicat., 38, 1062 (2002).

5) Y. Akiyama and T. Kuroda, The Paper of Technical Meeting on Rotating Machinery, IEE Japan, RM-99-28 (1999) [in Japanese].

6) S. S. Ramamurthy and J. C. Balda, IEEE Trans. Ind. Applicat., 37, 1256 (2001).

7) K. Nakamura, Y. Suzuki, H. Goto and O. Ichinokura, Journal of Magnetism and Magnetic Materials, 290-291, 1334 (2005).

8) K. Nakamura, K. Kimura, and O. Ichinokura, The Paper of Technical Meeting on Rotating Machinery, IEE Japan, RM-04-47 (2004) [in Japanese].

9) K. Nakamura, K. Kimura and O. Ichinokura, Journal of Magnetism and Magnetic Materials, 290-291, 1309 (2005).

10) T. Tsukii, K. Nakamura, and O. Ichinokura, T. IEE Japan, 122-D, 16 (2002) [in Japanese].

11) K. Tajima, O. Ichinokura, A. Kaga, and Y. Anazawa, $J$. Magn. Soc. Jpn., 19, 553 (1995) [in Japanese].

2005年10月 19 日受理， 2005年11月15日採録 